\title{
SUSCEPTIBILITY OF TWO KARYOTYPIC FORMS OF Anopheles aconitus (DIPTERA: CULICIDAE) TO Plasmodium falciparum AND P. vivax
}

\author{
Anuluck JUNKUM(1), Atchariya JITPAKDI(1), Narissara JARIYAPAN(1), Narumon KOMALAMISRA(2), Pradya SOMBOON(1), \\ Wannapa SUWONKERD(3), Aungkana SAEJENG(3), Paul A. BATES(4) \& Wej CHOOCHOTE(1)
}

\begin{abstract}
SUMMARY
Four laboratory-raised colonies of two karyotypic forms of Anopheles aconitus, i.e., Form B (Chiang Mai and Phet Buri strains) and C (Chiang Mai and Mae Hong Son strains), were experimentally infected with Plasmodium falciparum and $P$. vivax using an artificial membrane feeding technique and dissected eight and 12 days after feeding for oocyst and sporozoite rates, respectively. The results revealed that An. aconitus Form B and $\mathrm{C}$ were susceptible to $P$. falciparum and $P$. vivax, i.e., Form $\mathrm{B}$ (Chiang Mai and Phet Buri strains/P. falciparum and P. vivax) and Form $\mathrm{C}$ (Chiang Mai and Mae Hong Son strains/P. vivax). Comparative statistical analyses of the oocyst rates, average number of oocysts per infected midgut and sporozoite rates among all strains of An. aconitus Form $\mathrm{B}$ and $\mathrm{C}$ to the ingroup control vectors, An. minimus $\mathrm{A}$ and $\mathrm{C}$, exhibited mostly no significant differences, confirming the high potential vector of the two Plasmodium species. The sporozoite-like crystals found in the median lobe of the salivary glands, which could be a misleading factor in the identification of true sporozoites in salivary glands were found in both An. aconitus Form B and C.
\end{abstract}

KEYWORDS: Anopheles aconitus; Karyotypic form; Susceptibility; Plasmodium falciparum; P. vivax.

\section{INTRODUCTION}

Malaria remains a major health problem of the world, particularly, in the tropical ${ }^{41}$. In Thailand, four species of malaria parasites are found; the most common species are Plasmodium vivax $(52.50 \%)$ and $P$. falciparum $(45.89 \%)$, while $P$. malariae $(0.32 \%)$ and $P$. ovale (one case reported from Chiang Mai province in 1996) are rare, and $1.29 \%$ are mixed infections ${ }^{2}$. The disease is generally limited to rural communities living in and near forested areas, mountains and foothills, particularly, those residing in newly opened land settlements of semiforested areas earning their living by growing agricultural crops, and in the areas near and along the borders with the neighboring countries of Kampuchea, Laos, Myanmar and Malaysia ${ }^{1,2}$.

So far, at least six anopheline species have been incriminated as primary and secondary vectors of malaria in Thailand. The primary vectors are Anopheles dirus Peyton \& Harrison, An. minimus Theobald, and An. maculatus Theobald ${ }^{3,29,31,39}$. The taxa of above three vectors are all species complexes, and the members of each complex cannot be easily distinguished from each other ${ }^{4,6,15}$. The secondary vectors are An. sundaicus (Rodenwaldt), An. aconitus Donitz, and An. pseudowillmori (Theobald), one of the member species of An. maculatus complex $^{8,16,17,31}$. For An. aconitus, it was also incriminated as a vector of malaria in other countries, i.e., Indonesia ${ }^{20,21}$, Bangladesh ${ }^{22}$, Malaysia $^{24}$ and India ${ }^{23}$.

As early as 1944, An. aconitus was considered a primary vector of malaria in Thailand ${ }^{33}$. However, such implications lacked confirmation until GOULD et al. ${ }^{17}$ found one An. aconitus female positive for both oocysts and sporozoites, and another one positive for only oocysts by dissection in the rice plain just north of Bangkok in April and August, respectively. In addition, the human-baited, whom bitten during April was subsequently got infection with $P$. vivax. This area was known to be endemic for $P$. vivax essentially to the exclusion of all other Plasmodium species. Thus, the authors concluded that An. aconitus was obviously the vector. Additional positive specimens of An. aconitus have not been reported in Thailand up to this time, except the reports of positive ELISA for circumsporozoite (CS) antigens from southern Thailand $^{25}$. Recently, three karyotypic forms of An. aconitus, i.e., Form $\mathrm{A}\left(\mathrm{X}_{1}, \mathrm{X}_{2}, \mathrm{Y}_{1}\right), \mathrm{B}\left(\mathrm{X}_{1}, \mathrm{X}_{2}, \mathrm{Y}_{2}\right)$, and $\mathrm{C}\left(\mathrm{X}_{1}, \mathrm{X}_{2}, \mathrm{Y}_{3}\right)$ have been incriminated sympatrically from northern Thailand, while Form $\mathrm{D}\left(\mathrm{X}_{3}, \mathrm{X}_{4}, \mathrm{Y}_{4}\right)$ has been reported from only Java, Indonesia ${ }^{5}$. Apparently, little is known about the vector potential of An. aconitus in northern Thailand, particularly among the karyotypic forms, which is intensively needed to confirm its vector status. Hence the present study reports the susceptibility of An. aconitus Form B and C strains from Chiang Mai

(1) Department of Parasitology, Faculty of Medicine, Chiang Mai University, Chiang Mai 50200, Thailand.

(2) Department of Medical Entomology, Faculty of Tropical Medicine, Mahidol University, Bangkok 10400, Thailand.

(3) Office for Vector Borne Diseases Control 2, Department of Communicable Diseases Control, Ministry of Public Health, 18 Boonruangrit Road, Chiang Mai 50200, Thailand.

(4) Molecular and Biochemical Parasitology Group, Liverpool School of Tropical Medicine, University of Liverpool, Liverpool, United Kingdom.

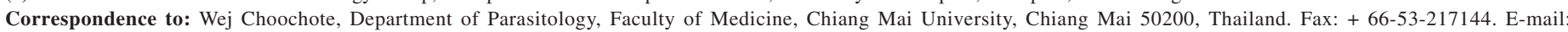
wchoocho@mail.med.cmu.ac.th 


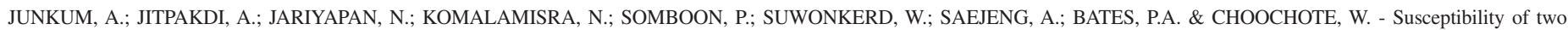
karyotypic forms of Anopheles aconitus (DIPTERA: CULICIDAE) to Plasmodium falciparum and P. vivax. Rev. Inst. Med. trop. S. Paulo, 47(6):333-338, 2005.

province (northern Thailand), Mae Hong Son province (northwest Thailand), and Phet Buri province (southwest Thailand) to P. falciparum and $P$. vivax.

\section{MATERIALS AND METHODS}

Laboratory-raised An. aconitus Form B and C: Three provinces, the endemic areas of malaria in Thailand, i.e., Chiang Mai (Ban Pang Mai Daeng, Maetang district), Mae Hong Son (Ban Huai Pong Kan, Muang district) and Phet Buri (Ban Tha Salao, Nong Ya Plong district), the same localities as the previous studies by JUNKUM et al. ${ }^{19}$, were the sites for mosquito collections by using both human-baited and buffalo-baited traps. Four laboratory-colony strains of An. aconitus were established based on metaphase karyotypes and localities. Since the results of metaphase karyotype identifications of 3, 4 and 89 isofemale lines (isolines) of An. aconitus strains from Mae Hong Son, Phet Buri and Chiang Mai, respectively, using the techniques of CHOOCHOTE et al. $^{11}$, revealed the two karyotypic forms, i.e., Form $\mathrm{B}\left(\mathrm{X}_{1}, \mathrm{X}_{2}, \mathrm{Y}_{2}\right)$, and $\mathrm{C}\left(\mathrm{X}_{1}, \mathrm{X}_{2}, \mathrm{Y}_{3}\right)$ (detailed descriptions of karyotypic forms were in the former studies by JUNKUM et al. ${ }^{19}$ ). Thus, two colonies of Form B, Phet Buri and Chiang Mai strains, were established by pooling 4 and 20 isolines, respectively. Two colonies of Form C, Mae Hong Son and Chiang Mai strains, were established by pooling 3 and 20 isolines, respectively. These colonies were successfully reared by using the method of CHOOCHOTE et al. ${ }^{12}$ in an insectary room at $27 \pm 2{ }^{\circ} \mathrm{C}, 70-80 \% \mathrm{RH}$, illuminated with a combination of natural daylight from glass-window and fluorescent lighting (approximately $12 \mathrm{~h}$ a day) for more than five consecutive generations, and were used for malarial susceptibility test throughout the experiments.

Outgroup and ingroup control vectors: The outgroup, An. dirus $\mathrm{B}$, a species member of An. dirus complex belongs to the leucosphyrus group, and the ingroup, An. minimus $\mathrm{A}$ and $\mathrm{C}$, the same taxon as $A n$. aconitus Form $\mathrm{B}$ and $\mathrm{C}$ in the Myzomyia series, were used as the control vectors in the malarial susceptibility experiments. An. dirus B was obtained originally from Armed Forces Research Institute of Medical Sciences (AFRIMS), Bangkok, Thailand, and the free-mating colony was establised in the insectarium of the Department of Parasitology, Faculty of Medicine, Chiang Mai University, Chiang Mai, Thailand for more than two decades. The free-mating colony of An. minimus A (CM strain) was from northern Thailand ${ }^{36}$. The CM strain was confirmed as species A by metaphase karyotypes and DNA sequence analysis of the D3 region of rDNA $^{37}$. For artificial mating colony of An. minimus $\mathrm{C}$, it was established by pooling 10 isolines of An. minimus $\mathrm{C}$ strain from Kanchanaburi province, central Thailand. All 10 isolines were identified to species $\mathrm{C}$ by using the combination characteristics of adults $^{38}$ and metaphase karyotypes ${ }^{5}$. Subsequently, additional evidence of species $\mathrm{C}$ was confirmed by DNA sequences of D3 region ${ }^{32}$.

$\boldsymbol{P}$ falciparum and $\boldsymbol{P}$. vivax gametocytes: The gametocytes of $P$. falciparum and $P$. vivax were obtained from malaria patients, whom got infection from Maetang and/or other districts in Chiang Mai province. Ten $\mathrm{mL}$ of blood containing gametocytes of the above malaria species were collected by venepuncture into a heparinized syringe, kept in ambient temperature $^{34}$, and used for infection of mosquitoes within $12 \mathrm{~h}$.

Infection of mosquitoes with $P$. falciparum and $P$. vivax gametocytes: After emergence, all adult female mosquitoes were provided with 5\% sucrose solution until age of 4-6 days, subsequently, they were fasted for 12 hours prior to the infections. The 12-hours fasted females of An. aconitus Form B and C, outgroup control mosquito-vector (An. dirus B), and ingroup control mosquito-vectors (An. minimus $\mathrm{A}$ and $\mathrm{C}$ ) were put in a paper cup size $8.5 \mathrm{~cm}$ in diameter and $11 \mathrm{~cm}$ in depth (50 fasted females per cup for each species), and allowed to feed on heparinized blood containing gametocytes (gametocyte density of $P$. falciparum $=21$ per $1 \mu \mathrm{L} ; P$. vivax $=28,17$ and 34 per $1 \mu \mathrm{L}$ in experiment 1,2 and 3, respectively) using artifial membrane feeding techniques as described by CHOMCHARN et al. ${ }^{10}$ The fully engorged females were separated to small paper cups (diameter $6.5 \mathrm{~cm}$, depth $8 \mathrm{~cm}$ ) with 10 mosquitoes per cup and maintained in an incubator at $27 \pm 2{ }^{\circ} \mathrm{C}, 70-80 \% \mathrm{RH}$. Cotton wool pad soaked with $5 \%$ sucrose solution was provided regularly and changed every other day until the time of dissections. Eight and twelve days after feeding, the infected mosquitoes were dissected and examined for oocysts in midguts and sporozoites in salivary glands, respectively.

\section{RESULTS}

Oocyst rates of An. dirus B, An. minimus A and C, and An. aconitus Form B and C: Details of oocyst rates are shown in Table 1. Observations on dissected midguts eight days after feeding revealed that An. aconitus Form B were susceptible to both $P$. falciparum and $P$. vivax, and Form $\mathrm{C}$ was susceptible to $P$. vivax . The $100 \%$ oocyst rates and 5.22 - 126.18 average number of oocysts per infected midgut obtained from An. dirus $\mathrm{B}$, the outgroup control mosquito-vector, indicated the all feedings were conditional experiments, which reflected on the proper density and maturity of infective gametocytes in infected blood.

In the experimental feedings of $P$. falciparum, the oocyst rates and average number of oocysts per infected midgut of An. aconitus Form B (Chiang Mai and Phet Buri strains) did not differed significantly ( $p$ $>0.05$ ) from the ingroup control-vector, An. minimus A. Similar results also were obtained from statistical analysis of the oocyst rates and average number of oocysts per infected midgut between An. aconitus Form B strains from Chiang Mai and Phet Buri provinces.

In the experimental feedings of $P$. vivax, mostly, the oocyst rates and average number of oocysts per infected midgut of An. aconitus Form B (Chiang Mai and Phet Buri strains) and C (Chiang Mai and Mae Hong Son strains) did not differ significantly $(p>0.05)$ from $A n$. minimus $\mathrm{A}$ and $\mathrm{C}$, except the average number of oocysts per infected midgut of An. aconitus Form C (Chiang Mai strain: experiment 1) was significantly less than that in An. minimus A, and Form C (Mae Hong Son strain: experiment 2) was significantly greater than that in the $A n$. minimus A. Similar results also were recovered from statistical analysis of the oocyst rates and average number of oocysts per infected midgut between An. aconitus Form B (Chiang Mai strain) and C (Chiang Mai and Mae Hong Son strains) in experiment 1 and 2, except for only the average number of oocysts per infected midgut of An. aconitus Form C (Mae Hong Son strain) was significantly greater than that in the Form B (Chiang Mai strain) in experiment 2.

Oocyst and sporozoite rates of An. dirus $\mathrm{B}, \mathrm{An}$. minimus $\mathrm{A}$ and C, and An. aconitus Form B and C: Details of oocyst and sporozoite rates are shown in Table 2. The dissection of midguts of An. dirus $\mathrm{B}$, An. minimus $\mathrm{A}$ and $\mathrm{C}$, and all strains of An. aconitus Form B and C 12 


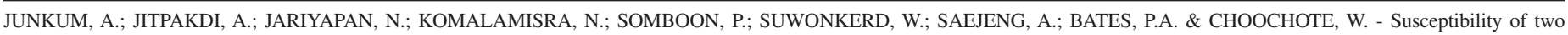
karyotypic forms of Anopheles aconitus (DIPTERA: CULICIDAE) to Plasmodium falciparum and P. vivax. Rev. Inst. Med. trop. S. Paulo, 47(6):333-338, 2005.

Table 1

The oocyst rates of An. dirus B, An. minimus A and C and An. aconitus Form B and C after feeding on blood containing gametocytes of $P$. falciparum and $P$. vivax, all dissected 8 days after feeding

\begin{tabular}{|c|c|c|c|c|c|c|c|}
\hline \multirow{4}{*}{ Malaria species } & \multicolumn{6}{|c|}{ Mosquito species } & \\
\hline & \multirow[t]{3}{*}{ An. dirus B } & \multicolumn{2}{|c|}{ An. minimus } & \multicolumn{4}{|c|}{ An. aconitus Form } \\
\hline & & \multirow[t]{2}{*}{ A } & \multirow[t]{2}{*}{$\mathrm{C}$} & \multicolumn{2}{|c|}{ B } & \multicolumn{2}{|c|}{$\mathrm{C}$} \\
\hline & & & & $\mathrm{CM}$ & $\mathrm{PB}$ & $\mathrm{CM}$ & MS \\
\hline \multicolumn{8}{|l|}{ P. falciparum } \\
\hline Oocyst rate (No.) & $100(20 / 20)$ & $91.67(11 / 12)$ & ND & $\begin{array}{c}62.50(5 / 8) \\
\text { NS }\end{array}$ & $\begin{array}{c}80.00(8 / 10) \\
\text { NS }\end{array}$ & ND & ND \\
\hline $\begin{array}{l}\text { Average No. oocysts per } \\
\text { Infected midgut (range) }\end{array}$ & $\begin{array}{l}84.75 \pm 45.53 \\
\quad(19-182)\end{array}$ & $\begin{array}{c}18.64 \pm 22.61 \\
(1-81)\end{array}$ & ND & $\begin{array}{l}31.40 \pm 21.85 \\
\mathrm{NS}(2-35)\end{array}$ & $\begin{array}{l}19.63 \pm 25.14 \\
\mathrm{NS}(1-79)\end{array}$ & & \\
\hline \multicolumn{8}{|l|}{ P. vivax } \\
\hline $\begin{array}{l}\text { Oocyst rate (No.) } \\
\text { Average No. oocysts per } \\
\text { Infected midgut (range) }\end{array}$ & $\begin{array}{c}100(7 / 7) \\
69.71 \pm 26.82 \\
(39-118)\end{array}$ & $\begin{array}{l}100(5 / 5) \\
18.00 \pm 6.93 \\
(11-27)\end{array}$ & $\begin{array}{l}\text { ND } \\
\text { ND }\end{array}$ & $\begin{array}{c}100(5 / 5) \\
10.00 \pm 6.04 \\
(4-19)\end{array}$ & $\begin{array}{l}\text { ND } \\
\text { ND }\end{array}$ & $\begin{array}{c}60.00(3 / 5) \mathrm{NS} \\
4.33 \pm 4.93 * \\
(1-10)\end{array}$ & $\begin{array}{l}\text { ND } \\
\text { ND }\end{array}$ \\
\hline \multicolumn{8}{|l|}{ Experiment 2} \\
\hline Oocyst rate (No.) & $90.00(9 / 10)$ & $83.33(5 / 6)$ & ND & $\begin{array}{c}66.67(4 / 6) \\
\text { NS }\end{array}$ & ND & ND & $\begin{array}{c}66.67(4 / 6) \\
\text { NS }\end{array}$ \\
\hline $\begin{array}{l}\text { Average No. oocysts per } \\
\text { Infected midgut (range) }\end{array}$ & $\begin{array}{l}5.22 \pm 3.73 \\
\quad(1-11)\end{array}$ & $\begin{array}{l}2.00 \pm 1.41 \\
(1-4)\end{array}$ & ND & $\begin{array}{c}1.00 \pm 0.00 \\
(1)\end{array}$ & ND & ND & $\begin{array}{c}6.00 \pm 3.46 * \\
(3-9)\end{array}$ \\
\hline \multicolumn{8}{|l|}{ Experiment 3} \\
\hline Oocyst rate (No.) & $100(11 / 11)$ & $81.82(9 / 11)$ & $\begin{array}{c}50.00(5 / 10) \\
\text { NS }\end{array}$ & ND & $\begin{array}{c}50.00(2 / 4) \\
\text { NS }\end{array}$ & ND & ND \\
\hline $\begin{array}{l}\text { Average No. oocysts per } \\
\text { Infected midgut (range) }\end{array}$ & $\begin{array}{c}126.18 \pm 55.92 \\
(34-223)\end{array}$ & $\begin{array}{l}22.78 \pm 15.18 \\
(2-54)\end{array}$ & $\begin{array}{l}7.80 \pm 8.23 \\
\mathrm{NS}(1-22)\end{array}$ & ND & $\begin{array}{c}19.50 \pm 12.02 \\
\mathrm{NS}(11-28)\end{array}$ & ND & ND \\
\hline
\end{tabular}

Mosquito strain; CM: Chiang Mai, MS: Mae Hong Son, PB: Phet Buri; Oocyst rate: NS, $p>0.05,{ }^{*}, p<0.05$ (Fisher exact test); Average No. oocysts per infected midgut: $\mathrm{NS}, p>0.05,{ }^{*}, p<0.05$ (t-test, two-sided); ND: not done.

days after feeding on blood containing $P$. falciparum and $P$. vivax gametocytes revealed that the oocyst rates were 95\% (An. aconitus Form B: Phet Buri strain), 96.30\% (An. aconitus Form B: Chiang Mai strain), $100 \%$ (An. minimus A), and $100 \%$ (An. dirus B), for $P$. falciparum, and 14.28-75\% (all strains of An. aconitus Form B and C), $39.13 \%$ (An. minimus C), 11.11-100\% (An. minimus A) and 15.79$100 \%$ (An. dirus B) for P. vivax. Statistical analyses of the oocyst rates among the ingroup control mosquito-vectors, An. minimus A and $\mathrm{C}$, and all strains of An. aconitus Form $\mathrm{B}$ and $\mathrm{C}$ were not done because at this period (12 days of postblood meal) the mature oocysts from the midgut of the control vectors ruptured and yielded unreliable results. Nonetheless, the satisfactory percentages of oocyst rates obtained from both outgroup and ingroup control-vectors were confirmed the conditional experiments.

The dissection of salivary glands 12 days after feeding demonstrated that An. aconitus Form B strains from Chiang Mai and Phet Buri were efficiently potential vectors for P. falciparum, and Form B strains from Chiang Mai and Phet Buri and Form $\mathrm{C}$ strains from Chiang Mai and Mae Hong Son were the efficiently potential vectors for $P$. vivax when compared to the ingroup control-vectors, An. minimus A and C. Comparative statistical analyses of sporozoite rates among An. minimus
A and $\mathrm{C}$, and four strains of An. aconitus Form B and C of all experiments exhibited no significant differences $(p>0.05)$, except only An. aconitus Form B (Phet Buri strain) differed significantly $(p<0.05)$ in the experimental feeding of $P$. falciparum.

Another interesting point in the present study is the sporozoitelike crystal found in the median lobe of salivary glands of both $A n$. aconitus Form B and C, i.e., Form B: Chiang Mai strain 3.70\% (1/27), Phet Buri strain 20\% (4/20) (experimental feeding on P. falciparum); Form C: Mae Hong Son strain $28.57 \%$ (4/14) (experimental feeding on $P$. vivax). The sporozoite-like crystal rather resembles a true sporozoite, particularly, when it is inside a non-squashed salivary glands. The latter has regular spindle-shaped while the former has irregular, long or short with blunt or tapered end(s) (Fig. 1). It was stable in $0.85 \%$ normal saline solution for at least half an hour and after that the dissolve of the crystal could be obviously seen, and could be easily distinguished from the true sporozoite.

\section{DISCUSSION}

In order to incriminate a mosquito vector in an endemic area of mosquito-borne human diseases, it is necessary to confirm the 


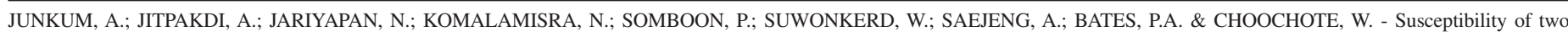
karyotypic forms of Anopheles aconitus (DIPTERA: CULICIDAE) to Plasmodium falciparum and P. vivax. Rev. Inst. Med. trop. S. Paulo, 47(6):333-338, 2005.

Table 2

The oocyst and sporozoite rates of An. dirus $\mathrm{B}$, An. minimus A and $\mathrm{C}$ and An. aconitus Form $\mathrm{B}$ and $\mathrm{C}$ after feeding on blood containing gametocytes of $P$. falciparum and $P$. vivax, all dissected 12 days after feeding

\begin{tabular}{|c|c|c|c|c|c|c|c|}
\hline \multirow{4}{*}{ Malaria species } & \multicolumn{6}{|c|}{ Mosquito species } & \\
\hline & \multirow[t]{3}{*}{ An. dirus $\mathrm{B}$} & \multicolumn{2}{|c|}{ An. minimus } & \multicolumn{4}{|c|}{ An. aconitus Form } \\
\hline & & \multirow[t]{2}{*}{ A } & \multirow[t]{2}{*}{$\mathrm{C}$} & \multicolumn{2}{|c|}{ B } & \multicolumn{2}{|c|}{$\mathrm{C}$} \\
\hline & & & & $\mathrm{CM}$ & $\mathrm{PB}$ & $\mathrm{CM}$ & MS \\
\hline \multicolumn{8}{|l|}{ P. falciparum } \\
\hline Oocyst rate (No.) & $100(23 / 23)$ & $100(11 / 11)$ & ND & $96.30(26 / 27)$ & $95.00(19 / 20)$ & ND & ND \\
\hline $\begin{array}{l}\text { Average No. oocysts per } \\
\text { Infected midgut (range) }\end{array}$ & $\begin{array}{l}85.00 \pm 26.41 \\
(39-145)\end{array}$ & $\begin{array}{l}5.45 \pm 3.86 \\
(1-15)\end{array}$ & ND & $\begin{array}{c}13.35 \pm 15.60 \\
(1-54)\end{array}$ & $\begin{array}{l}28.58 \pm 28.42 \\
\quad(2-90)\end{array}$ & ND & ND \\
\hline Sporozoite rate (No.) & $\begin{array}{c}95.65 \\
(22 / 23)\end{array}$ & $\begin{array}{c}100 \\
(11 / 11)\end{array}$ & ND & $\begin{array}{c}70.37 \\
(19 / 27) \mathrm{NS}\end{array}$ & $\begin{array}{c}45.00 \\
(9 / 20) *\end{array}$ & ND & ND \\
\hline \multicolumn{8}{|l|}{ P. vivax } \\
\hline Oocyst rate (No.) & $100(4 / 4)$ & $100(2 / 2)$ & ND & ND & ND & $100(4 / 4)$ & ND \\
\hline $\begin{array}{l}\text { Average No. oocysts per } \\
\text { Infected midgut (range) }\end{array}$ & $\begin{array}{l}28.00 \pm 25.07 \\
\quad(6-64)\end{array}$ & $\begin{array}{c}5.50 \pm 4.95 \\
(2-9)\end{array}$ & ND & ND & ND & $\begin{array}{l}9.75 \pm 4.03 \\
(5-14)\end{array}$ & ND \\
\hline Sporozoite rate (No.) & $100(4 / 4)$ & $100(2 / 2)$ & ND & ND & ND & $100(4 / 4)$ & ND \\
\hline \multicolumn{8}{|l|}{ Experiment 2} \\
\hline Oocyst rate (No.) & $15.79(3 / 19)$ & $11.11(1 / 9)$ & ND & $16.67(2 / 12)$ & ND & ND & $14.28(2 / 14)$ \\
\hline $\begin{array}{l}\text { Average No. oocysts per } \\
\text { Infected midgut (range) }\end{array}$ & $\begin{array}{c}1.33 \pm 0.58 \\
(1-2)\end{array}$ & $\begin{array}{c}1.00 \pm 0.00 \\
(1)\end{array}$ & ND & $\begin{array}{c}2.00 \pm 1.41 \\
(1-3)\end{array}$ & ND & ND & $\begin{array}{c}1.00 \pm 0.00 \\
(1)\end{array}$ \\
\hline Sporozoite rate (No.) & $\begin{array}{c}80.00 \\
(16 / 20)\end{array}$ & $\begin{array}{c}33.33 \\
(3 / 9)\end{array}$ & ND & $\begin{array}{c}16.67 \\
(2 / 12) \mathrm{NS}\end{array}$ & ND & ND & $\begin{array}{c}14.28 \\
(2 / 14) \mathrm{NS}\end{array}$ \\
\hline \multicolumn{8}{|l|}{ Experiment 3} \\
\hline Oocyst rate (No.) & $100(17 / 17)$ & $66.67(12 / 18)$ & $39.13(9 / 23)$ & ND & $75.00(9 / 12)$ & ND & ND \\
\hline $\begin{array}{l}\text { Average No. oocysts per } \\
\text { Infected midgut (range) }\end{array}$ & $\begin{array}{c}33.53 \pm 20.12 \\
\quad(7-77)\end{array}$ & $\begin{array}{c}2.92 \pm 1.24 \\
(1-5)\end{array}$ & $\begin{array}{c}2.89 \pm 1.83 \\
(1-6)\end{array}$ & ND & $\begin{array}{c}2.89 \pm 2.15 \\
(1-7)\end{array}$ & ND & ND \\
\hline Sporozoite rate (No.) & $100(17 / 17)$ & $77.78(14 / 18)$ & $\begin{array}{c}52.17 \\
(12 / 23) \mathrm{NS}\end{array}$ & ND & $\begin{array}{c}66.67 \\
(8 / 12) \mathrm{NS}\end{array}$ & ND & ND \\
\hline
\end{tabular}

Mosquito strain; CM: Chiang Mai, MS: Mae Hong Son, PB: Phet Buri; Sporozoite rate: NS, $p>0.05,{ }^{*}, p<0.05$ (Fisher exact test, $\chi^{2}$-test for only experiment 3); ND: not done.

susceptibility rate in a laboratory-bred, clean mosquito colony that has been fed on a carrier blood containing pathogens ${ }^{30}$. Thus, by using this criterion, the susceptibility test in an experimental laboratory is still a useful tool when suspecting the potential vector of a certain mosquito species. Nevertheless, the susceptibility alone does not imply an important role in the transmission of disease in nature, whereas a refractory one can entirely rule out its significance. According to the vectorial status of An. aconitus to P. falciparum and $P$. vivax as
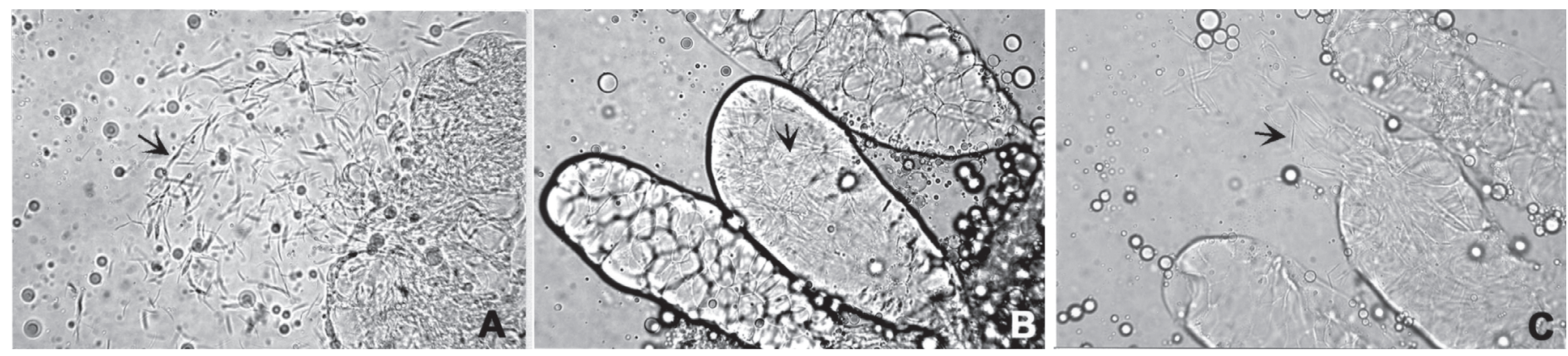

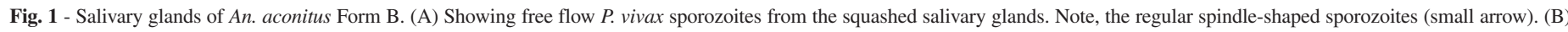

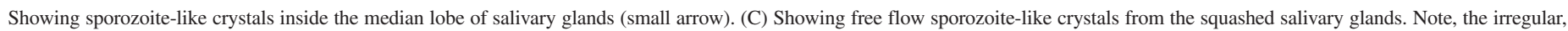
long or short, crystals with blunt or tapered end(s) (small arrow). 


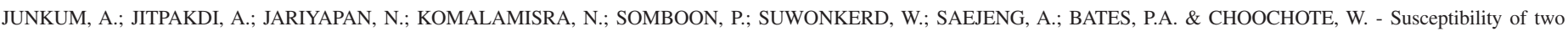
karyotypic forms of Anopheles aconitus (DIPTERA: CULICIDAE) to Plasmodium falciparum and P. vivax. Rev. Inst. Med. trop. S. Paulo, 47(6):333-338, 2005.

determined by the susceptibility tests using a laboratory-bred, clean mosquito colony have never been done and/or reported before this time. The high oocyst and sporozoite rates of An. aconitus Form B strains from Chiang Mai and Phet Buri provinces to infection with $P$. falciparum, and Form B strains from Chiang Mai and Phet Buri provinces and Form $\mathrm{C}$ strains from Chiang Mai and Mae Hong Son provinces to infection with $P$. vivax in the present study, confirming the secondary vector status of An. aconitus as reported by GOULD et $a l .{ }^{17}$. Nonetheless, further investigations on the oocyst and sporozoite rates of wild-caught female An. aconitus in an endemic area of malaria in Chiang Mai province and/or other suspected areas should be done intensively to determine its role as a naturally transmissive vector.

Many Thailand Anopheles species have been reported positive ELISA for circumsporozoite (CS) antigens of $P$. falciparum and $P$. vivax by using the whole body and/or head and thorax of mosquitoes $7,13,14,18,25$. This diagnostic tool did not definitely incriminate the mosquito as the natural vector, since it could be detected CS protein from the developing oocysts ${ }^{9}$, soluble CS protein shed from oocysts and sporozoites ${ }^{40}$ and CS protein in various body parts ${ }^{26}$. In addition, false positive $P$. falciparum and $P$. vivax detections by ELISA were reported ${ }^{35}$. However, the mosquito species which were highly susceptible to malarial infections could not be incriminated as the potential vectors, since sporozoite did not invade salivary glands ${ }^{28}$. Judged from the above evidences, therefore, the combining of positive ELISA for CS antigens with sporozoite rate of a laboratory-bred, clean Anopheles colony should be the important evidences prior to the incrimination of potentially natural vector.

Additionally, the sporozoite-like crystal found in the median lobe of salivary glands of An. aconitus Form B and C might be one of the important, missed leading factor in the identification of true sporozoite in salivary glands of the laboratory susceptibility experiments and/or wild-caught Anopheles females. Similar results have been reported in An. sinensis Form $\mathrm{A}$ and $\mathrm{B}^{27}$.

\section{RESUMO}

\section{Suscetibilidade de duas formas cariotípicas de Anopheles aconitus (Diptera: Culicidae) a Plasmodium falciparum e $P$. vivax}

Quatro colônias desenvolvidas em laboratório, de duas formas cariotípicas de Anopheles aconitus i.e. forma B (cepa Chiang Mai e Phet Buri) e C (Cepa Chiang Mai e Mae Hong Son), foram infectadas experimentalmente com Plasmodium falciparum e $P$. vivax usando técnica de alimentação com membrana artificial e dissecados oito e 12 dias após alimentação da média de oocistos e esporozoitos, respectivamente. Os resultados revelaram que An. aconitus formas B e C foram suscetíveis ao $P$. falciparum e $P$. vivax isto é, forma B (cepa Chiang Mai e Phet Buri/P. falciparum e $P$. vivax) e forma $\mathrm{C}$ (cepa Chiang Mai e Mae Hong Son/P. vivax). Análises estatísticas comparativas das taxas de oocistos, número médio de oocistos por intestino médio infectado e taxas de esporozoitos entre todas as cepas de An. aconitus formas $\mathrm{B}$ e $\mathrm{C}$ ao grupo interno de vetores controles, An. minimus A e C, não exibiram nenhuma diferença significante, confirmando o alto potencial vetor das duas espécies de Plamodium. Os cristais semelhantes a esporozoitos encontrados no lobo médio das glândulas salivares que poderiam ser um fator enganoso na identificação de esporozoitos verdadeiros nas glândulas salivares foram encontrados em ambos An. aconitus formas B e C.

\section{ACKNOWLEDGEMENTS}

The authors sincerely thank the Thailand Research Fund (TRF: BRG/14/2545) and the Royal Golden Jubilee Ph.D Program (Grant No. PHD/0044/2546) for financially supporting this research project, Professor Supot Wudhikarn, Dean of the Faculty of Medicine, Chiang Mai University, for his interest in this research, and the Faculty of Medicine Endowment Fund for Research Publication for its financial support in defraying publication costs.

\section{REFERENCES}

1. ANNUAL REPORT - Thailand, Division of Malaria, Department of Communicable Disease Control, Ministry of Public Health, 1998

2. ANNUAL REPORT - Thailand, Division of Malaria, Department of Communicable Disease Control, Ministry of Public Health, 2002.

3. AYURAKITKOSOL, L. \& GRIFFITH, M.E. - Progress toward malaria eradication in Thailand. In: PROCEEDINGS OF THE PACIF. SCI. CONGRESS, 9., Bangkok, 1957. v. 17 , p. $122-136,1963$.

4. BAIMAI, V.; GREEN, C.A.; ANDRE, R.G.; HARRISON, B.A. \& PEYTON, L.E. Cytogenetic studies of some species complexes of Anopheles in Thailand and Southeast Asia. Southeast Asian J. trop. Med. publ. Hlth., 15: 536-546, 1984.

5. BAIMAI, V.; KIJCHALAO, U. \& RATTANARITHIKUL, R. - Metaphase karyotypes of Anopheles of Thailand and Southeast Asia. V. The Myzomyia series, Subgenus Cellia (Diptera: Culicidae). J. Amer. Mosq. Contr. Ass., 12: 97-105, 1996.

6. BAIMAI, V.; KIJCHALAO, U.; RATTANARITHIKUL, R. \& GREEN, C.A. - Metaphase karyotypes of Anopheles of Thailand and Southeast Asia. II. Maculatus group, Neocellia series, Subgenus Cellia. Mosq. Syst., 25: 116-123, 1993.

7. BAKER, E.Z.; BEIER, J.C.; MEEK, S.R. \& WIRTZ, R.A. - Detection and quantification of Plasmodium falciparum and P. vivax infections in Thai-Kampuchean Anopheles (Diptera: Culicidae) by enzyme-linked immunosorbent assay. J. med. Entomol., 24: 536-541, 1987.

8. BARNES, M.E. - Notes on the anopheline mosquitoes of Siam. Amer. J. Hyg., 3: 121126, 1923.

9. BEIER, J.C.; PERKINS, P.V.; WIRTZ, R.A. et al - Field evaluation of an enzyme-linked immunosorbent assay (ELISA) for Plasmodium falciparum sporozoite detection in anopheline mosquitoes from Kenya. Amer. J. trop. Med. Hyg., 36: 459-468, 1987.

10. CHOMCHARN, Y.; SURATHIN, K.; BUNNAG, D.; SUCHARIT, S. \& HARINASUTA, T. - Effect of a single dose of primaquine on a Thai strain of Plasmodium falciparum. Southeast Asian J. trop. Med. publ. HIth, 11: 408-412, 1980.

11. CHOOCHOTE, W.; PITASAWAT, B.; JITPAKDI, A. et al. - The application of ethanolextracted Gloriosa superba for metaphase chromosome preparation in mosquitos. Southeast Asian J. trop. Med. publ. Hlth, 32: 76-82, 2001.

12. CHOOCHOTE, W.; SUCHARIT, S. \& ABEYEWICKREME, W. - A note on adaptation of Anopheles annularis Van Der Wulp, Kanchanaburi, Thailand, to free mating in a 30x30x30 cm cage. Southeast Asian J. trop. Med. publ. Hlth, 14: 559-560, 1983.

13. FRANCES, S.P.; KLEIN, T.A.; WIRTZ, R.A. et al. - Plasmodium falciparum and $P$. vivax circumsporozoite proteins in anophelines (Diptera: Culicidae) collected in eastern Thailand. J. med. Entomol., 33: 990-991, 1996. 
JUNKUM, A.; JITPAKDI, A.; JARIYAPAN, N.; KOMALAMISRA, N.; SOMBOON, P.; SUWONKERD, W.; SAEJENG, A.; BATES, P.A. \& CHOOCHOTE, W. - Susceptibility of two karyotypic forms of Anopheles aconitus (DIPTERA: CULICIDAE) to Plasmodium falciparum and P. vivax. Rev. Inst. Med. trop. S. Paulo, 47(6):333-338, 2005.

14. GINGRICH, J.B.; WEATHERHEAD, R.A.; SATTABONGKOT, A.; PILAKASIRI, J. \& WIRTZ, R.A. - Hyperendemic malaria in a Thai village: dependence of year-round transmission on focal and seasonally circumscribed mosquito (Diptera: Culicidae) habitats. J. med. Entomol., 27: 1016-1026, 1990.

15. GREEN, C.A.; GASS, R.F.; MUNSTERMANN, L.E. \& BAIMAI, V. - Population-genetic evidence for two species in Anopheles minimus in Thailand. Med. vet. Entomol., 4: 25-34, 1990.

16. GREEN, C.A.; RATTANARITHIKUL, R.; PONGPARIT, S.; SAWADWONGPORN, P. \& BAIMAI, V. - A newly-recognized vector of human malarial parasites in the Oriental region, Anopheles (Cellia) pseudowillmori (Theobald, 1910). Trans. roy. Soc. trop. Med. Hyg., 85: 35-36, 1991.

17. GOULD, D.J.; ESAH, S. \& PRANITH, U. - Relation of Anopheles aconitus to malaria transmission in the central plain of Thailand. Trans. roy. Soc. trop. Med. Hyg., 61: 441-442, 1967

18. HARBACH, R.E.; GINGRICH, J.B. \& PANG, L.W. - Some entomological observations and malaria transmission in a remote village in Northwestern Thailand. J. Amer. Mosq. Contr. Ass., 3: 296-301, 1987.

19. JUNKUM, A.; JITPAKDI, A.; KOMALAMISRA, N. et al. - Comparative morphometry and morphology of Anopheles aconitus Form B and C eggs under scanning electron microscope. Rev. Inst. Med. trop. S. Paulo, 46: 257-262, 2004.

20. KIRNOWARDOYO, S. - Status of Anopheles malaria vectors in Indonesia. Southeast Asian J. trop. Med. publ Hith., 16: 129-132, 1985.

21. KIRNOWORDOYO, S. \& SUPALIN - Zooprophylaxis as useful tool for control of Anopheles aconitus transmitted malaria in central Java, Indonesia. J. commun. Dis., 18: 90-94, 1986.

22. MAHESWARY, N.P.; HABIB, M.A. \& ELIAS, M. - Incrimination of Anopheles aconitus Donitz as a vector of epidemic malaria in Bangladesh. Southeast Asian J. trop. Med. publ. Hlth, 23: 798-801, 1992.

23. PRAKASH, A.; BHATTACHARYYA, D.R.; MOHAPATRA, P.K. \& MAHANTA, J. Role of the prevalent Anopheles species in the transmission of Plasmodium falciparum and P. vivax in Assam state, north-eastern India. Ann. trop. Med. Parasit., 98: 559$568,2004$.

24. RAHMAN, W.A.; ABU-HASSAN, A. \& ADANAN, C.R. - Seasonality of Anopheles aconitus mosquitoes, a secondary vector of malaria, in an endemic village near the Malaysia-Thailand border. Acta trop., 55: 263-265, 1993.

25. RATTANARITHIKUL, R.; KONISHI, E. \& LINTHICUM, K.J. - Detection of Plasmodium vivax and Plasmodium falciparum circumsporozoite antigen in anopheline mosquitoes collected in southern Thailand. Amer. J. trop. Med. Hyg., 54: 114-121, 1996.

26. ROBERT, V.; VERHAVE, J.P.; PONNUDURAI, T. et al. - Study of the distribution of circumsporozoite antigen in Anopheles gambiae infected with Plasmodium falciparum, using the enzyme-linked immunosorbent assay. Trans. roy. Soc. trop. Med. Hyg., 82: 389-391, 1988.

27. RONGSRIYAM, Y.; JITPAKDI, A.; CHOOCHOTE, W. et al. - Comparative susceptibility of two forms of Anopheles sinensis Wiedemann 1828 (Diptera: Culicidae) to infection with Plasmodium falciparum, $P$. vivax, $P$. yoelii and the determination of misleading factor for sporozoite identification. Southeast Asian J. trop. Med. publ. HIth, 29: 159-167, 1998
28. ROSENBERG, R. - Inability of Plasmodium knowlesi sporozoites to invade Anopheles freeborni salivary glands. Amer. J. trop. Med. Hyg., 34: 687-691, 1985.

29. ROSENBERG, R.; ANDRE, R.G. \& SOMCHIT, L. - Highly efficient dry season transmission of malaria in Thailand. Trans. roy. Soc. trop. Med. Hyg., 84: 22-28, 1990

30. SASA, M. - Human filariasis: a global survey of epidemiology and control. Tokyo, University of Tokyo Press, 1976.

31. SCANLON, J.E.; PEYTON, E.L \& GOULD, D.J. - An annotated checklist of the Anopheles of Thailand. Thai nat. Sci. Pap. Fauna. Ser., 2: 1-35, 1968.

32. SHARPE, R.G.; HIMS, M.M.; HARBACH, R.E. \& BUTLIN, R.K. - PCR-based methods for identification of species of the Anopheles minimus group: allele-specific amplification and single-strand conformation polymorphism. Med. vet. Entomol., 13: $265-273,1999$

33. SIMMONS, J.S.; WHAYNE, T.F.; ANDERSON, G.W. \& HORACK, H.M. - Global epidemiology. A geography of disease and sanitation. Philadephia, J.B. Lippincott, 1944. v.1, p. 504.

34. SOMBOON, P. \& MORAKOTE, N. - Infectivity of gametocytes of Plasmodium falciparum and Plasmodium vivax after storage in vitro. Ann. trop. Med. Parasit., 84: 89-91, 1990.

35. SOMBOON, P.; MORAKOTE, N.; KOOTTATHEP, S. \& TRISANAROM, U. - Detection of sporozoites of Plasmodium vivax and Plasmodium falciparum in mosquitoes by ELISA: false positivity associated with bovine and swine blood. Trans. roy. Soc. trop. Med. Hyg., 87: 322-324, 1993.

36. SOMBOON, P. \& SUWONKERD, W. - Establishment of a stenogamous colony of Anopheles minimus species A. Ann. trop. Med. Parasit., 91: 673-676, 1997.

37. SOMBOON, P.; WALTON, C.; SHARPE, R.G. et al. - Evidence for a new sibling species of Anopheles minimus from the Ryukyu Archipelago, Japan. J. Amer. Mosq. Contr. Ass., 17: 98-113, 2001.

38. SUCHARIT, S.; KOMALAMISRA, N.; LEEMINGSAWAT, S.; APIWATHNASORN, C. \& THONGRUNGKIAT, S. - Population genetic studies on the Anopheles minimus complex in Thailand. Southeast Asian J. trop. Med. publ. Hlth, 19: 717-723, 1988.

39. VEJJASASTRA, P. - Malaria survey at Tung Song, Nakhon Si Thamarat. Department of Health (Thailand). Publ. Hlth Bull., (11), 1933. (in Thai).

40. VERHAVE, J.P.; LEEUWENBERG, A.D.; PONNUDURAI, T.; MEUWISSEN, J.H. \& VAN DRUTEN, J.A. - The biotin-streptavidin system in a two-site ELISA for the detection of plasmodial sporozoite antigen in mosquitoes. Parasite Immunol., 10: $17-31,1988$

41. WORLD HEALTH ORGANIZATION - Wkly epidem. Rec., 32: 265-272, 1999.

Received: 24 November 2004

Accepted: 5 August 2005 